\title{
EDITORIAL DEPARTMENT
}

WILLIAM LOUDEN, INVENTOR AND MANUFACTURER

William I.ouden was born in Cassville, Huntingdon County, Pennsylvania, October 16, 1841, and died in Fairfield, Iowa, November 5, 1931. Burial was in Evergreen Cemetery, Fairfield. His parents, Andrew and Jane (Speer) Louden, in 1842 removed with their family to a farm in Jefferson County, Iowa, seven miles sontheast of Fairfield. William acquired his education in country schools and in Fairfield University, a school long since abandoned.

After teaching school a few terms he engaged in farming, but his talent for mechanics and invention led him into efforts to improve tools and contrivances used by farmers and in 1870 he removed to Fairfield and established a small factory for making barn fixtures. His first patent (1867) was for a hay carrier, which came into use quite generally all over the country. From 1871 to 1876 his little factory prospered, but the hard times of that period were disastrous to him, rendering him penniless. For the next several years he traveled over the country putting up his hay carriers, and in 1883 he re-established his factory. In 1889 his brother, R. B. Louden, and in 1892 Charles J. Fulton, joined with him in organizing the Louden Machinery Company, which later established branches in various parts of the United States and Canada. The company made everything in barn equipment, and came to be recognized throughout the country as the leader in this line, especially in dairy articles.

Mr. Louden also led in the organization and development of the Iowa Malleable Iron Company of Faireld, and was a director and president of the Fairfield Chautauqua. In his active career he was awarded 118 different patents on farm, and factory devices, and by his talent, energy and enterprise contributed materially to the welfare of agriculture.

The Country Gentleman for January, 1932, betokened in the 
following language the respect in which the agricultural country at large held Mr. Louden:

\section{WILLIAM LOUDEN}

Nearly everyone who works in a barn provided with modern laborsaving equipment has reason to regret the passing of William Louden, of Fairfield, Iowa. His inventions for use in the barn were on the same plane as those of McCormick, John Deere and others in the field.

The first hay carrier was manufactured by him in a little shop on his father's Iowa farm. He invented the first flexible barndoor hanger, the principle of which is used in practically every door hanger today. From his efforts came the first patented manure carrier, as well as many other now commonly used devices that have made work in the barn quicker and easier. And many farmers owe the good construction and convenience of their barns to the barn-planning service which he established and made free to all who needed it.

There was still another distinctive feature to William Louden's career. His business, by then growing nicely, was swept completely away in the prolonged panic that began in 1873. Despite the gloomy counsel of others he began all over again, with a firm faith in himself, his country and the work he was doing. The country needs his kind and his spirit now.

\section{THE VERNON WOOLEN FACTORY}

On Monday last we had the pleasure of taking a tramp through the extensive woolen mills of Allender \& Ketchum of Vernon. Although a resident of the town, it had been over a year since we had taken a view of the interior of the establishment, since which time it has been almost wholly fitted out with new machinery of the latest improved patterns adopted to the most exquisite manipulations of the fibre. $*^{* * * *}$ What most interested us was to see the amount and variety of machinery, pickers, fullers, carding machines, spinning jacks, looms and dressing machines. They have three spinning jacks in operation and will soon have eleven looms going, with a capacity for turning out about 2,000 yards of cloth per week.-The Bentonsport Signal, Bentonsport, Iowa, April 23, 1868. (In the Newspaper Division of the Historical, Memorial and Art Department of Iowa.) 
Copyright of Annals of Iowa is the property of State of Iowa, by \& through the State Historical Society of Iowa and its content may not be copied or emailed to multiple sites or posted to a listserv without the copyright holder's express written permission. However, users may print, download, or email articles for individual use. 